\title{
Analysis of Knowledge About Rapid Tests With Behavior of Undergoing Covid 19 Rapid Tests in Late Third Trimester Pregnant Women at Tumbang Kalang Health Center, East Kotawaringin Regency, Central Kalimantan Province
}

\author{
Lingga Kusuma Wardani, Reski \\ Fauzianti \\ Institut Ilmu Kesehatan STRADA \\ Indonesia \\ Email: \\ reskifauzianti@gmail.com
}

Received : October $4^{\text {nd }} 2021$

Accepted : October $15^{\text {rd }} 2021$

Published : November 27 2021

\section{ABSTRACT}

Introduction : Lack of knowledge of pregnant women about rapid tests so that the behavior of pregnant women sometimes does not take part in the Covid 19 rapid test because they are afraid, worried about the action. The purpose of this study was to determine the relationship between knowledge about rapid tests and the behavior of undergoing rapid tests for Covid 19 in late third trimester pregnant women at the Tumbang Kalang Health Center, East Kotawaringin Regency, Central Kalimantan Province.

Methods : The design of this study is a correlational study with a cross sectional approach. Respondents were taken by simple random sampling technique. The population is 38 pregnant women with a sample of 35 pregnant women. The independent variable is knowledge about rapid tests and the dependent variable is the behavior of undergoing the Covid 19 rapid test. The results are analyzed using the Spearman rank statistical test.

Results : The results showed that almost all of the respondents as many as 29 (83\%) respondents had good knowledge of rapid tests. Most of the respondents as many as 26 (74\%) respondents behaved well in undergoing the Covid 19 rapid test.

Analysis : The results of data analysis showed that the significance level was $0.000<=0.05$ so that $\mathrm{H} 0$ was rejected and $\mathrm{H} 1$ was accepted, thus there is a relationship between knowledge about rapid tests and behavior in undergoing Covid 19 rapid test for pregnant women in the third trimester at the Tumbang Kalang Health Center, East Kotawaringin Regency, Central Kalimantan Province.

Disscusion : Based on the results of the study, it was concluded that the higher the knowledge of pregnant women about the Covid 19 rapid test, the better the attitudes and behavior of pregnant women in undergoing the Covid 19 rapid test. Knowledge of pregnant women about the Covid 19 rapid test obtained from various sources such as electronic media, officers Health is able to increase the knowledge of pregnant women about the benefits and objectives of the Covid-19 rapid test.

Keywords: Covid 19, pregnant women, knowledge, behavior, rapid test 
Analysis of Knowledge About Rapid Tests.....

Copyright @ 2021 IIK STRADA Indonesia

All right reserved.

ShareAlike 4.0 International License.

\section{INTRODUCTION}

The problem that is often faced today is that pregnant women have to undergo a Covid 19 rapid test. This becomes a burden for pregnant women to take part in these activities. Pregnant women feel anxious when doing a Covid 19 rapid test because of the lack of knowledge of pregnant women about rapid tests. The behavior of pregnant women sometimes does not take the Covid 19 rapid test because of fear and the wrong perception of pregnant women, where with the rapid test pregnant women will contract Covid 19. Thus, pregnant women make the decision not to undergo the Covid 19 rapid test. Health (Sari, 2020). The World Health Organization (WHO) (2021), shows the latest update of Covid 19 in the world on June 25, 2021 as many as 177,988,379 cases. WHO (2021), said that in the UK, 472 pregnant women were hospitalized with Corona Virus with their babies during the pandemic.

Some of the women in the study required only normal care and were discharged in good condition, about one in ten women required intensive care and five women died, although it is not yet known whether the virus was the cause of death. To date, no research has found a cure or vaccine for the Covid-19 virus. This virus is a new virus so there is no evidence that shows an increased risk of miscarriage. However, there is evidence to suggest that mother-to-child transmission may occur during pregnancy or birth. All over the world there are reports that some babies are born prematurely to some unwell mothers with Corona Virus. But it is not clear whether this virus causes premature birth.

Research in the UK shows that in one out of five babies born prematurely and admitted to the neonatal unit, fewer than 20 babies are born very prematurely. Transmission of Corona Virus infection from mother to baby is low (WHO, 2021). Data from the Ministry of Health of the Republic of Indonesia (2021), shows the latest update of Covid 19 in Indonesia on June 25, 2021, as many as $2,053,995$ cases. The Indonesian Ministry of Health (2021), said that pregnant women are listed as one of the vulnerable groups at risk of being infected with Covid-19 because during pregnancy physiological changes occur which result in a partial decrease in immunity and can cause serious impacts for pregnant women. Information about Covid-19 is still very limited, including data on pregnant women who have been confirmed positive for Covid-19, but cannot be concluded in Indonesia. The results of the study of 55 pregnant women and 46 neonates who were infected with Covid-19 could not confirm the existence of vertical transmission and it is not known whether it increases the number of miscarriages and stillbirths.

The results of research conducted by (Schwartz, 2020) found that 37 pregnant women who were confirmed to have Covid-19 via PCR did not find severe pneumonia and/or maternal death, among 30 neonates who were born there were no confirmed cases of Covid-19. Until now, knowledge about Covid-19 infection in relation to pregnancy and the fetus is still limited and there are no specific recommendations for handling pregnant women with Covid-19 (Kemenkes RI, 2021). The Covid 19 Task Force for Central Kalimantan Province (2021), the number of Covid 19 cases to date is 14,907 positive, 13094 people recovered and 374 people died.

While the latest update on March 17, 2021 regarding the development of Covid 19 in East Kotawaringin Regency, it is known that 85 people are suspected, 0 people are Probable, 1,598 people confirmed, 1,426 people recovered, 45 people died (Media Center Task Force Covid 19 Central Kalimantan, 2021 ). Data on the number of Covid 19 cases obtained from the East Kotawaringin Health Service (2021) are known to be 30 people with suspected cases, 167 confirmed cases, 10 dead, 97 recovered. The results of a preliminary study conducted by researchers on April 26, 2021 at the Tumbang Kalang Health Center, East Kotawaringin Regency, Central Kalimantan Province with interviews with 10 pregnant women, it was found that pregnant women were afraid to undergo a rapid test. The perception of pregnant women that they will be infected with Covid 19 after these actions are carried out. So that the behavior of pregnant women does not follow the rapid test. One of the pregnant 
women refuses to undergo a Covid 19 rapid test (Results of a Preliminary Study with Interviews with Respondents at the Tumbang Kalang Health Center, East Kotawaringin Regency, Central Kalimantan Province, 2021).

One of the factors related to the behavior of pregnant women in undergoing rapid tests is the knowledge of pregnant women. Knowledge of pregnant women is needed to be able to undergo rapid tests where pregnant women who have adequate knowledge of rapid tests, the behavior of pregnant women will undergo rapid tests without any fear and worry about the action, and vice versa. Knowledge has a significant relationship to the behavior of pregnant women in undergoing rapid tests. Knowledge cannot be separated from one's behavior, including pregnant women themselves. Good knowledge of pregnant women will guide pregnant women to take decisions in action, especially in undergoing rapid tests (DepKes, 2021). Gaining good knowledge of information certainly requires efforts such as reading books, watching television news, even from scientific journals. Information obtained from mass media as well as electronic, printed and non-printed media, does not necessarily change the behavior of pregnant women in undergoing rapid tests if they are not filtered properly and support from various parties, both families and communities and even health workers, is needed. 2021).

Knowledge is the result of someone knowing about a certain object. A person's knowledge is influenced by the sense of hearing, the sense of sight, the sense of smell, the sense of taste and touch, but mostly influenced by the eyes and ears. Knowledge itself is influenced by educational factors, where it is expected that someone who is highly educated has high knowledge too, but that does not mean those with low education also have low knowledge (Notoatmodjo, 2017). Covid-19 is a newly discovered disease, therefore knowledge related to its prevention is being explored by world scientists. The key to prevention includes breaking the chain of transmission with early detection, isolation and basic protection. Until now, knowledge about Covid-19 infection in relation to pregnancy and the fetus is still limited and there are no specific recommendations for handling pregnant women with Covid-19 (Kemenkes, 2020).

The solution to be able to overcome the above problems is that pregnant women need to increase their knowledge about the Covid 19 rapid test with efforts such as reading books, watching television news even from scientific journals so that they can change the mother's behavior in undergoing the Covid 19 rapid test. Besides that, providing information and education regarding guidelines for pregnant women in the era of the COVID-19 pandemic and danger signs of pregnancy through health counseling can be given to pregnant women in order to increase knowledge and change the behavior of pregnant women in undergoing the Covid 19 rapid test because good knowledge of pregnant women will lead pregnant women to take decisions to act, especially on Covid-19 screening with rapid tests. Besides that, good knowledge of pregnant women in the final third trimester will guide pregnant women to take decisions in action, especially the behavior of pregnant women in undergoing the Covid 19 rapid test. Gaining good knowledge of information certainly requires efforts such as reading books, watching television news and even from scientific journals. Information obtained from mass media as well as electronic, printed and non-printed, does not necessarily change preventive behavior if it is not filtered properly and support from various parties, both families and the surrounding community is needed. Based on the background of the problem above, the researchers are interested in conducting a research entitled "Analysis of Knowledge About Rapid Tests With Behavior Undergoing Rapid Tests for Covid 19 in Late Third Trimester Pregnant Women at Tumbang Kalang Health Center, East Kotawaringin Regency, Central Kalimantan Province".

\section{FORMULATION OF THE PROBLEM}

Based on the background of the problem above, the problem that can be formulated is is there a "Relationship between Knowledge About Rapid Tests and Behavior of Undergoing Covid 19 Rapid Tests in Late Third Trimester Pregnant Women at Tumbang Kalang Health Center, East Kotawaringin Regency, Central Kalimantan Province"?

\section{RESEARCH PURPOSES}

1. General Objectives The purpose of this study was to determine the relationship between knowledge about rapid tests and the behavior of undergoing rapid tests for Covid 19 in late third trimester pregnant women at the Tumbang Kalang Health Center, East Kotawaringin Regency, Central Kalimantan Province. 


\section{Special Purpose}

a) Identifying Knowledge About Rapid Tests in Late Third Trimester Pregnant Women at Tumbang Kalang Health Center, East Kotawaringin Regency, Central Kalimantan Province.

The research design used in this study is a correlational study with a cross sectional approach. The population in this study were all 38 pregnant women in the third trimester with a sample of 35 people. In this study, the independent variable was Knowledge of Rapid Tests and the dependent variable was the Behavior of Undergoing the Covid 19 Rapid Test in Late Third Trimester Pregnant Women. This research was conducted at the Tumbang Kalang Public Health Center, East Kotawaringin Regency, Central Kalimantan Province. Data processing through the stages of editing, coding, scoring, tabulation. The statistical test used is Spearman rank with a value of $=0.05$.

\section{RESEARCH RESULTS AND DISCUSSION}

A. Knowledge of Rapid Tests for Late Third Trimester Pregnant Women at Tumbang Kalang Health Center, East Kotawaringin Regency, Central Kalimantan Province. all respondents as many as $29(83 \%)$ respondents have good knowledge of rapid tests. This is in accordance with the statement of one pregnant woman in the results of the questionnaire that the rapid test is one way to detect Covid-19 infection in the human body and aims to stop the spread of the corona virus. A statement from one respondent that the rapid test begins by taking a blood sample from the tip of the finger and then dropping it into the rapid test kit. In addition, one of the mothers said that the Government required pregnant women to undergo a Covid 19 rapid test at the nearest health service/clinic. The results of the study also found that a small proportion of respondents had less knowledge as many as $4(11 \%)$ respondents and $2(6 \%)$ respondents had sufficient knowledge. This shows that there is a lack of information for pregnant women about rapid tests so that the behavior of pregnant women feels afraid and anxious and does not even take part in the rapid tests carried out by health workers. The perception of one mother that she will be infected with Covid 19 if a rapid test is carried out so that the wrong perception of pregnant women has an impact on the lack of behavior in undergoing the Covid 19 rapid test. Covid 19. The results of the questionnaire are also known that the lack of behavior of pregnant women in undergoing rapid tests is due to the absence of their own transportation at home to make it easier for mothers to undergo For the Covid 19 rapid test, pregnant women do not have sufficient funds to pay for transportation (car/gojek) to visit the Puskesmas during the Covid 19 rapid test. Kalang, East Kotawaringin Regency, Central Kalimantan Province, it is known that almost all respondents aged 2535 years as many as $24(80 \%)$ respondents have good knowledge of rapid tests. This shows that the age of pregnant women is closely related to the mother's knowledge about the Covid 19 rapid test. The more mature the age of the pregnant woman, the better her knowledge about the benefits and objectives of rapid tests carried out by health workers. On the other hand, where the knowledge of pregnant women is not good, they tend not to know about the benefits and objectives of the rapid test, even the behavior of the mother does not undergo and refuses to do the rapid test.

Notoatmodjo (2017), said that the more mature a person's age, the more positive his attitudes and behavior will be towards health. In the opinion of the researcher, the more mature the age of pregnant women, the better their knowledge will be supported by experience, information obtained by pregnant women, especially knowledge about the Covid 19 rapid test. Tumbang Kalang, East Kotawaringin Regency, Central Kalimantan Province, it is known that almost all respondents with a high school education level as many as 18 (95\%) respondents have good knowledge of rapid tests. This shows that pregnant women are well knowledgeable about rapid tests where information obtained from health workers about the importance of pregnant women undergoing rapid tests during pregnancy, is able to increase the knowledge of pregnant women about the benefits and objectives of undergoing rapid tests. Notoatmodjo (2017) says that education is an experience that with that experience, a person can understand something that does not know to know. The experience occurs because there is an interaction between a person or group and their environment. This interaction causes a process of change in humans and then the process of change produces developments for the life of a person or group in their environment.

In the opinion of the researcher, good education for pregnant women can support the knowledge of pregnant women about the benefits and goals of undergoing the Covid 19 rapid test. Knowledge of pregnant women about rapid tests is obtained from various sources such as health workers, electronic media so as to increase knowledge about the Covid rapid test. 19. Based on the 
results of the cross tabulation between Occupation and Knowledge of Rapid Tests for Late Third Trimester Pregnant Women at the Tumbang Kalang Health Center, East Kotawaringin Regency, Central Kalimantan Province, it is known that almost all respondents work as Farmers/IRT as many as 20 (80\%) respondents have good knowledge about rapid test. This shows that with the work of pregnant women as IRT where the behavior of pregnant women always accesses the latest news about the spread of the corona virus to date. Besides that, pregnant.

Able to know about the Covid 19 rapid test from health workers. Adi (2020), said that work is the main activity carried out by humans to be able to meet their daily needs. In the opinion of the researcher, the busyness of pregnant women in doing a job every day is similar to the respondent's job as IRT, even though with her busyness in taking care of the household the respondent remains active in accessing the latest news about the spread of the corona virus so as to increase the knowledge of pregnant women about Covid 19 and its prevention.

Knowledge of pregnant women about rapid tests or swab tests that are chosen to detect the Covid-19 corona virus in the body early. There is also a type of rapid test that can be used to detect Covid-19, namely the rapid antigen test. The implementation of the rapid antigen test is carried out with new tools and materials, the packaging is also ensured that it is not open. To ensure the packaging is in good condition, pregnant women are invited to check and open the packaging so that pregnant women know that the tools used are appropriate. Most pregnant women only know in detail the tools used for rapid tests. In this case, pregnant women increase their knowledge about the rapid antigen test. This is reinforced that knowledge is the basis of the level of warning about self-awareness of health (DepKes, 2020).

In the opinion of researchers, the higher the knowledge of pregnant women about the Covid 19 rapid test, the better the attitudes and behavior of pregnant women in undergoing the Covid 19 rapid test. Knowledge of pregnant women about the Covid 19 rapid test obtained from various sources such as electronic media, health workers are able to increase insight into the knowledge of pregnant women about the benefits and objectives of the Covid 19 rapid test. In addition, the Government also requires pregnant women to undergo a Covid 19 rapid test at the nearest health service/clinic. Thus, pregnant women always obey the recommendations of the Government and the behavior of pregnant women is always obedient in implementing the Covid 19 health protocol during pregnancy. Health workers must always remind pregnant women to always maintain the physical condition of the fetus in the womb by living clean and healthy behaviors such as consuming nutritious food, being active in checking pregnancy at the nearest health service and always implementing health protocols such as wearing a mask when visiting the Puskesmas, washing hands, keep your distance, stay away from crowds to avoid contagion of Covid 19. B.

Based on the results of the study, it was found that the behavior of undergoing a Covid 19 rapid test for late third trimester pregnant women at the Tumbang Kalang Health Center, East Kotawaringin Regency, Central Kalimantan Province was known that most of the respondents as many as $26(74 \%)$ respondents behaved well in undergoing the Covid 19 rapid test. This shows that pregnant women behave well in undergoing the Covid 19 rapid test supported by adequate facilities and infrastructure in the family, the availability of funds to pay for transportation when visiting the Puskesmas, support from family and husband in supporting the behavior of mothers undergoing rapid tests. So that with these various facilities and support, it is able to improve the behavior of pregnant women in undergoing the Covid 19 rapid test. The results also found that a small percentage of respondents behaved less as much as $6(17 \%)$ respondents and $3(9 \%)$ respondents behaved fairly.

This is supported by the lack of facilities and infrastructure, the lack of funds to support the behavior of mothers undergoing the Covid 19 rapid test. Based on the results of the cross tabulation between Age and Behavior of Undergoing Covid 19 Rapid Tests for Late Third Trimester Pregnant Women at the Tumbang Kalang Health Center, East Kotawaringin Regency, Central Kalimantan Province, it is known that most of the respondents aged 25-35 years as many as 21 (70\%) respondents behaved well in undergoing

the Covid 19 rapid test. This shows that the more mature the age of the pregnant woman, the better the behavior of pregnant women in undergoing the Covid 19 rapid test.

Notoatmodjo (2017), says that the older a person is, the level of maturity and strength of a person will be more mature in thinking and taking actions that are beneficial to him. In the opinion of the researcher that the more mature the age of pregnant women, the more life experiences they will have, and it is 
easier to accept changes in behavior, because this age is the most productive age and the most ideal age in playing a role, especially in the formation of health activities, in this case the behavior of pregnant women in undergoing rapid test for Covid 19.

Based on the results of the cross-tabulation between Education and Behavior of Undergoing the Covid 19 Rapid Test for Late Third Trimester Pregnant Women at the Tumbang Kalang Health Center, East Kotawaringin Regency, Central Kalimantan Province, it is known that almost all respondents with a high school education level as many as $16(84 \%)$ respondents behaved well in undergoing rapid Covid 19 test. This shows that with good education for pregnant women, it can support the behavior of pregnant women about the Covid 19 rapid test. Notoatmodjo (2017) said that the lower a person's education level, the less health behavior. And vice versa, where the higher the level of education of a person, the better his health attitude and behaviour.

Pregnant women are at high risk due to changes in the immunology and physiology of the gestational system in the body system of pregnant women so that they can increase the risk of transmitting Covid 19. During a pandemic like the current period, pregnancy check-ups are carried out to optimize the mental and physical health of pregnant women. The ANC period in the current pandemic is carried out by adding screening for the first semester, especially the behavior of pregnant women in undergoing the Covid-19 rapid test as one of the government's efforts to suppress the spread of Covid-19. The importance of the behavior of pregnant women undergoing rapid tests because in addition to the potential to transmit the virus to the newborn, during childbirth, the mother also has the potential to transmit the virus to health workers (Nakes). Because in the process of giving birth, the mother will push and scream.

The government then implemented a health protocol in which pregnant women were required to undergo a rapid test or swab before giving birth. In the opinion of the researcher, the behavior of pregnant women in undergoing the COVID-19 rapid test is supported by the existence of adequate facilities and infrastructure in the family, the availability of funds to pay for transportation when visiting the Puskesmas, support from family and husbands in supporting the behavior of mothers undergoing rapid tests. So that with these various facilities and support, they are able to improve the behavior of pregnant women in undergoing the Covid 19 rapid test. In addition, the attitudes and behavior of pregnant women do not feel afraid and anxious because pregnant women are able to know the benefits and objectives of the Covid 19 rapid test carried out by health workers. even from various media such as electronic media so as to improve the behavior of pregnant women in undergoing the Covid 19 rapid test. C.

The Relationship of Knowledge About Rapid Tests With Behavior Undergoing Rapid Tests for Covid 19 in Late Third Trimester Pregnant Women at Tumbang Kalang Health Center, East Kotawaringin Regency, Central Kalimantan Province. The results of data analysis show that the significance level is $0.000<=0.05$ so $\mathrm{H} 0$ is rejected and $\mathrm{H} 1$ is accepted accordingly There is a relationship between knowledge about rapid tests and the behavior of undergoing rapid tests for Covid 19 in late third trimester pregnant women at the Tumbang Kalang Health Center, East Kotawaringin Regency, Central Kalimantan Province. Based on the results of the cross tabulation between Knowledge about Rapid Tests and Behavior of Undergoing Covid 19 Rapid Tests in Late Third Trimester Pregnant Women at the Tumbang Kalang Health Center, East Kotawaringin Regency, Central Kalimantan Province, it is known that almost all respondents are knowledgeable and well behaved in undergoing the Covid 19 rapid test, namely 26 (90\%) respondents.

One of the factors related to the behavior of pregnant women in undergoing rapid tests is the knowledge of pregnant women. Knowledge of pregnant women is needed to be able to undergo rapid tests where pregnant women who have adequate knowledge of rapid tests, the behavior of pregnant women will undergo rapid tests without any fear and worry about the action. Knowledge has a significant relationship to the behavior of pregnant women in undergoing rapid tests. Knowledge cannot be separated from one's behavior, including pregnant women themselves (Notoatmodjo, 2017).

Good knowledge of pregnant women will guide pregnant women to take decisions in action, especially in undergoing rapid tests (DepKes, 2021). Gaining good knowledge of information certainly requires efforts such as reading books, watching television news, even from scientific journals. Information obtained from mass media as well as electronic, printed and non-printed media, does not necessarily change the behavior of pregnant women in undergoing rapid tests if they are not filtered properly and support from various parties, both families and communities and even health workers, is 
needed. 2021). The solution to be able to overcome the above problem is where pregnant women need to increase their knowledge about the Covid 19 rapid test with efforts such as reading books, watching television news even from scientific journals so that they can change the mother's behavior in undergoing the Covid 19 rapid test.

Besides that, the provision of information and education about guidelines for pregnant women in the era of the COVID-19 pandemic and danger signs of pregnancy through health counseling can be given to pregnant women in order to increase knowledge and change the behavior of pregnant women in undergoing rapid tests for Covid 19 because of good knowledge of mothers. Pregnant women will guide pregnant women to make decisions in acting, especially in screening for Covid-19 with rapid tests. Besides that, good knowledge of pregnant women in the final third trimester will guide pregnant women to take decisions in action, especially the behavior of pregnant women in undergoing the Covid 19 rapid test. Gaining good knowledge.

\section{CONCLUSION}

Based on the results of the study, it was concluded that knowledge about rapid tests in late third trimester pregnant women at the Tumbang Kalang Health Center, East Kotawaringin Regency, Central Kalimantan Province, it was known that almost all of the respondents as many as 29 (83\%) respondents had good knowledge of rapid tests. The Behavior of Undergoing Covid 19 Rapid Tests for Pregnant Women in the Final Third Trimester At the Tumbang Kalang Health Center, East Kotawaringin Regency, Central Kalimantan Province, it is known that the majority of respondents as many as 26 (74\%) respondents behaved well in undergoing the Covid 19 rapid test. The results of data analysis showed that the level of significance $0.000<=0.05$ so that $\mathrm{H} 0$ is rejected and $\mathrm{H} 1$ is accepted. Thus, there is a relationship between knowledge about the rapid test and the behavior of undergoing the Covid 19 rapid test for pregnant women in the late third trimester at the Tumbang Kalang Health Center, East Kotawaringin Regency, Central Kalimantan Province.

It is recommended that health workers can provide information to health workers and the need for support from health workers in providing knowledge to pregnant women about the importance of the Covid 19 rapid test so that pregnant women do not feel anxious and afraid of the actions to be taken. Pregnant women are also expected to be able to add insight and increase knowledge of pregnant women about Covid 19 screening with rapid tests and also pregnant women can carry out pregnancy checks by implementing the Covid 19 prevention health protocol.

\section{REFERENCES}

A.Aziz, Alimul Hidayat. 2017. Metode Penelitian Keperawatan Dan Teknik Analisis Data. Jakarta : Penerbit. Salemba Medika.

Darwis, S. D. 2017. Metode Penelitian. Jakarta : EGC.

DepKes RI. 2020. Profil Kesehatan Indonesia 2020 : Menuju Indonesia Sehat 2020. Jakarta : Departemen Kesehatan RI.

Gugus Tugas Penanganan Covid 19, 2021

Kamus Besar Bahasa Indonesia (KBBI), 2016. Konsep Dasar Pengetahuan. Edisi Ketiga. Jakarta : Balai Pustaka.

Kementerian Kesehatan Republik Indonesia, 2021. Pedoman Kesiapsiagaan Menghadapi Infeksi Novel Coronavirus (2019-nCov). Direkorat Jenderal Pencegahan Dan Pengendalian Penyakit, 0-74.

Mandriawati, 2017. Penuntun Belajar Asuhan Kebidanan Ibu Hamil. Jakarta: EGC

Maksum, KH,A. 2017. Konsep Pengetahuan, pendidikan pesantren, Fakultas Agama Islam Universitas Alma Ata Yogyakarta 2017. Mubarak, 2017. Faktor-faktor yang mempengaruhi pengetahuan. Jakarta;Balai Pustaka.

Notoatmodjo, Soekidjo. 2017. Metodologi Penelitian Kesehatan. Jakarta : Rineka Cipta. Notoatmodjo, Soekidjo. 2017. Konsep Pengetahuan, Pendidikan dan Perilaku Kesehatan. Jakarta, EGC.

Nursalam, 2017. Konsep dan Penerapan Metodologi Penelitian Ilmu Keperawatan. Jakarta : Salemba Medika. 
Pantiawati, Ika. dan Saryono. 2017. Asuhan Kebidanan 1 Kehamilan. Nuha Medika.

Yogyakarta. Prawiroharjo, Sarwono. 2017. Ilmu kebidanan. (Edisi IV). Jakarta:yayasan bina pustaka

sarwono prawirohardjo. Prof. Dr. Mar'at, 2019. Pengetahuan, Sikap Manusia Perubahan serta Pengukurannya (Jakarta: Ghalia Indonesia, 2019) p. 10.

Pudiastuti, 2019. Asuhan Kebidanan Ibu I (Kehamilan). Yogyakarta: Rohima Press.

Saifuddin dkk, Abdul Bari. 2017. Buku Panduan Praktis Pelayanan Kesehatan Maternal Neonatal. Jakarta: Yayasan Bina Pustaka

Sarwono Prawirohardjo. Salmah, Rusmiati. Maryanah. dan Susanti. 2018. Asuhan Kebidanan

Antenatal.

EGC. Jakarta.

Sugiyono, 2017. Metode Penelitian Kuantitatif Kualitatif Dan R\&D (Edisi Revisi). Bandung : CV.

Alfabeta.

Sulistyawati, Ari. 2016. Asuhan Kebidanan Pada Masa Kehamilan. Salemba Medika. Jakarta.

Suparto Darudiato, Kevin Setiawan, 2016, Knowledge Management: Konsep dan Metodologi. ISSN 2085-4579 ULTIMA InfoSys, Vol. IV, No. 1.

Survey Demografi dan Kesehatan Indonesia (SDKI), 2020. Pedoman Pelayanan Antenatal Terpadu. Jakarta. SDKI, 2020. 